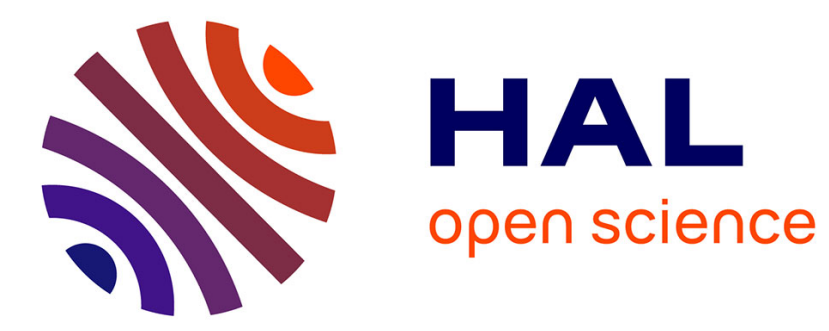

\title{
Insulin Release and Inhibition of Fore-Stomach Motility in Sheep
}

\author{
T.E.C Weekes, Lionel Bueno, Rafael Garcia Villar
}

\section{To cite this version:}

T.E.C Weekes, Lionel Bueno, Rafael Garcia Villar. Insulin Release and Inhibition of Fore-Stomach Motility in Sheep. Hormone and Metabolic Research, 1976, 8 (03), pp.238-239. 10.1055/s-00281095605 . hal-01562308

\section{HAL Id: hal-01562308 \\ https://hal.science/hal-01562308}

Submitted on 13 Jul 2017

HAL is a multi-disciplinary open access archive for the deposit and dissemination of scientific research documents, whether they are published or not. The documents may come from teaching and research institutions in France or abroad, or from public or private research centers.
L'archive ouverte pluridisciplinaire HAL, est destinée au dépôt et à la diffusion de documents scientifiques de niveau recherche, publiés ou non, émanant des établissements d'enseignement et de recherche français ou étrangers, des laboratoires publics ou privés.

\section{다(1)(2)}

Distributed under a Creative Commons Attribution - ShareAlikel 4.0 International 
Horm. Metah. Res $8(1976) 238239$

(C) Gearg Thieme Verlag Stuttgart

\title{
Insulin Figlease and Inhibition of Fore-Stomach Motility in Sheap
}

\author{
T.E.C. Weekes ${ }^{1}$, L. Buénoªnd R. Garcia-Villar ${ }^{2}$
}

Iho Rowett Research Institute, Aberdeen, Scotland and

¿Ecole Nationale Vétérinaire, Toulouse, France

\section{Introusuetion}

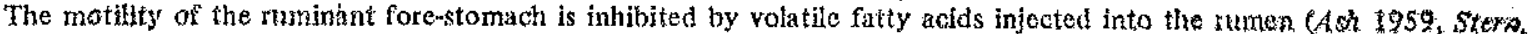
Baile and Wayef 1970) or infused intravenously (Le Bars, Lebrument, Nitescu and Simontet 1954), butyrato boing more effective than propionate or acetate. Intravenous butyrate also stimulates secretion of immunoreactive insulin (INI) ant gib cagon (IRG) (Bassett 1972), the lattor producing a hyperglycaemic response (Jones, Bell, Oyler and Goetseb 1970). Wo therefore investigated the effect of glucose, insulin and glucagon on the response of the reticulum to butyrate.

\section{Materiaśs and Menthods}

Thxee adult female sheep $(40+50 \mathrm{~kg}$ ) were equipped with electrodes for recording reticular motlity (Ruekebusch knd Tomen 1973). Sodium butyrate $(0.5 \mathrm{mmol} / \mathrm{kg}$ body weight; $0.5 \mathrm{M}$; pll 7.4) was injected into the jugular vein and juguhar blood. semples taken at interyals of 10-30 min. Similar injections were made $2 \mathrm{~h}$ after intravenous injections of elucagan ( $1 \mathrm{mg}$ is

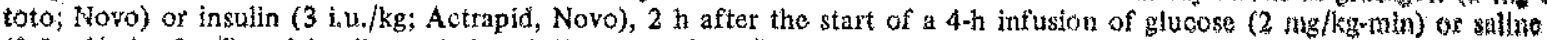
$(2.5 \mathrm{~m} / \mathrm{min}, 9 \mathrm{~g} / \mathrm{l})$ and in alloxan-induced diabetes $(70 \mathrm{mg} / \mathrm{kg}, 3$ days proviously). Reducing sugar was determined using a Technicon Auts Andyzer and plasma IRI according to Bassett and Thorburn (1971).

\section{Results and Discussion}

Table. Effects of butysate injection at time $0^{\prime}$ and glucose infusion on reticulum motility (contractions/li), plasma mI $(\mu \mathrm{U} / \mathrm{ml})$ and plasma glucose $(\mathrm{mg} / 100 \mathrm{ml})$ (mean \pm S.E.M. $) n^{*}=$ significant inhibition of motility $(\mathrm{p}<0,05)$

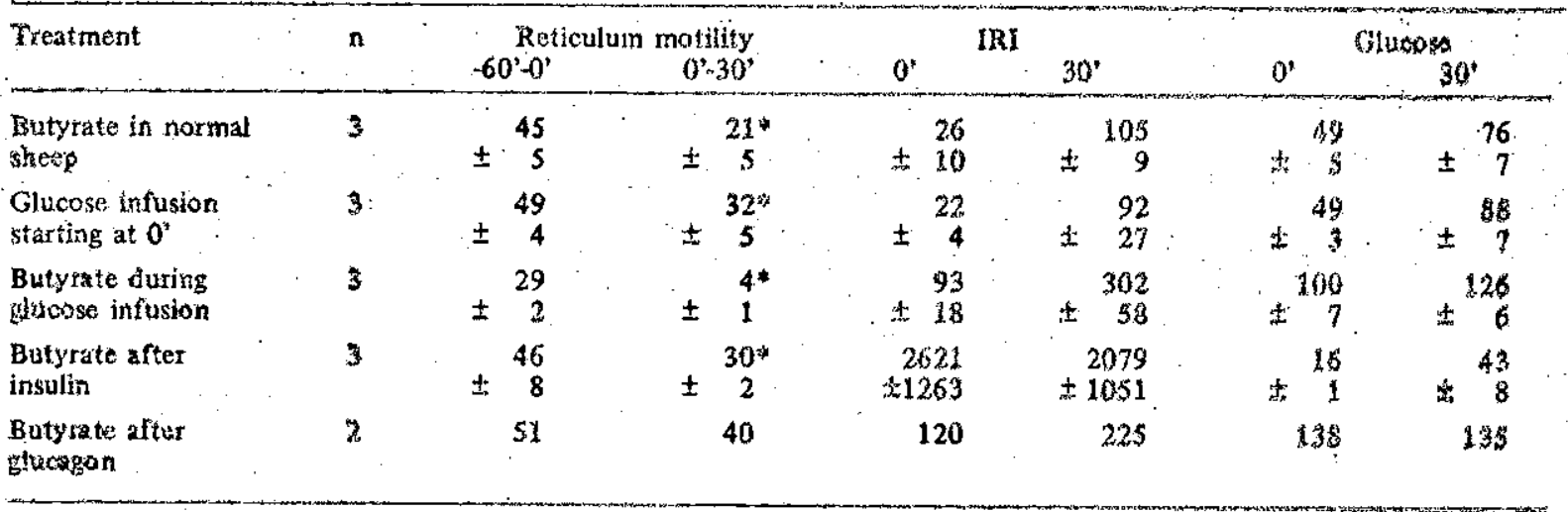

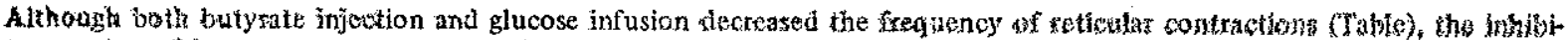

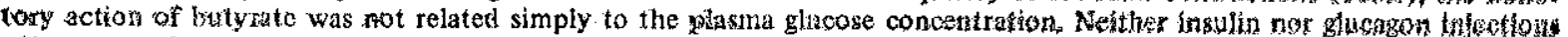

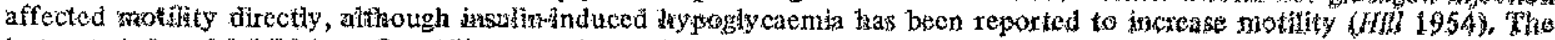

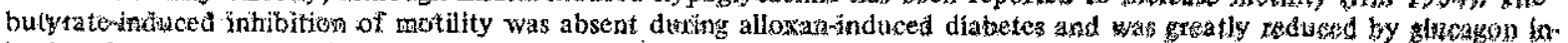

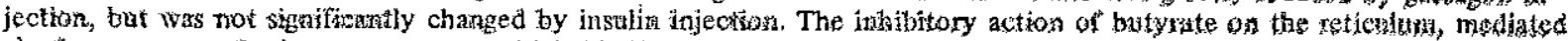

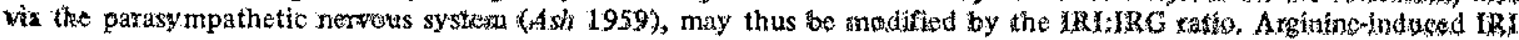

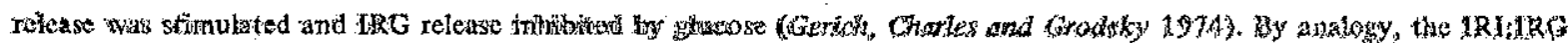

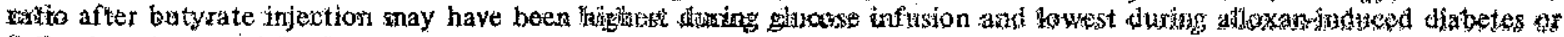
following glackson injection.

Rerectacs

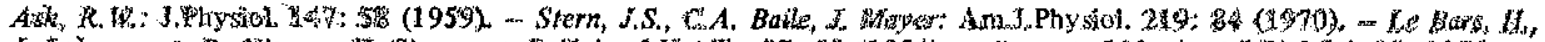

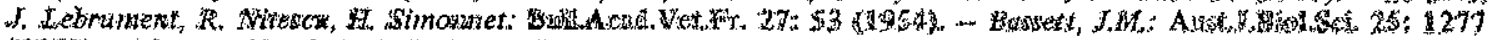

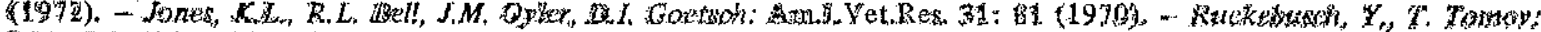

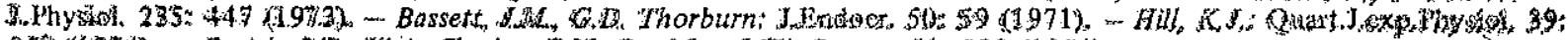

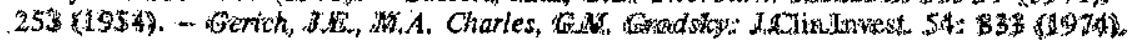

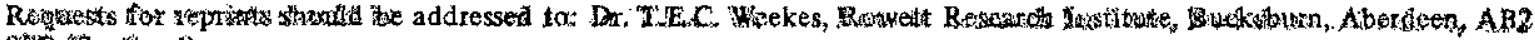
cosis (Sowitand) 